\title{
CHILDREN AND ADOLESCENTS IN VIRTUAL SPACE: GIRLS' AND BOYS' BEHAVIOUR AND ATTITUDE TO PARENTAL CONTROL
}

\author{
Renata Geležinienè \\ Rita Melienè \\ Asta Vaitkevičienè \\ Šiauliai University, Lithuania
}

\begin{abstract}
The article deals with the problem of children's and adolescents' activity in virtual space and parental control with regard to this activity. The question is raised what children and adolescents are most often doing in virtual space, for what goals they are using it; it is analysed whether there are any principal differences between boys' and girls' activities in virtual space. It is also disclosed how parents control children's and adolescents' online activities, how children perceive this control and what teachers think about this. The article reveals peculiarities of boys' and girls' activity in virtual space, peculiarities of teachers' and children's, adolescents' attitude to parental control with regard to virtual space.
\end{abstract}

Keywords: adolescents, children, educators, parents, virtual space.

\section{Introduction}

The importance of the computer in the child's and adolescent's life is increasingly growing: it turns into the tool of learning, communication and the means of spending leisure. According to the European survey data, Lithuanian schools are best provided with computer projectors, quite well equipped with computers (approaching the EU average) and interactive whiteboards (close to the EU average) but the number of laptop computers with web access and other devices in Lithuania is significantly lower than the EU average; therefore, this could be taken into account developing the infrastructure ${ }^{11}$. In Lithuania the generation of children is growing, to whom the computer as the means of selfexpression, learning, cognition, communication occupies a very important place. Often their computer literacy is significantly higher than educators' or parents' computer literacy, while activities in virtual environment are more intense and diverse than adults responsible for them believe. The question what children are doing online and how this affects their personality worries everybody: politicians, scientists, educators and, of course, most of all, parents. There are different opinions and scientists (Laurutis at al., 2003; Dagienè, 2003; Brazdeikis, 2003; Markauskaite \& Dagienè, 2001) emphasize advantages of the use of ICT in education and the learning process (it is stated that it contributes to

\footnotetext{
11“What are the trends of ICT integration in education in the society heading for intelligence?" The Analysis of the Education Problem. 2014, August, No. 5 (110). http://www.smm.lt/uploads/lawacts/docs/575_46f3997c7600580297a1e780bc9f3957.pdf
} 
creation of new and enriched diversity of information sources and means of communication, learning environment, which facilitates integration of various subjects, application of active teaching methods, development of children's individual abilities, teaching to work individually and in a group), analyze the impact on the personality because children and young people surfing the Internet encounter information and games containing unwanted content.

The study conducted by Masiliauskiene (2009) demonstrates that parents treat the computer as the tool for learning, providing comprehensive development opportunities, and tend to deny its importance for children's leisure activities because they do not associate computer aided activity with meaningful leisure. Besides, parents first of all think about consequences of misuse of the computer and only later about causes. They believe that bans are not the most effective way to avoid children's computer addiction and that it is possible to prevent excessive computer use through arousing interest in alternative activities and teaching safe behaviour.

Giles \& Price (2008) studied the Australian adolescents' (12-19 years old) computer usage habits and parental control peculiarities. The study disclosed that adolescents' greater perceptions of maternal control were associated with greater problematic effects from computer use. On one hand, mothers are more available to monitor computer use behaviour, on the other hand, the subjective sense of strong control may force adolescents to resist, leading to undesirable behaviour as an expression of protest. Yu at al. (2012), studying pupils' homebased computer use habits, identified the following factors related to children's computer use habits: parental ICT skills, parental monitoring, parental control, parental guidance and parental worries. It was identified that if parents' computer literacy was low or they used the Internet little, individuals outside the immediate family acted as experts and authorities to their children. Parents are particularly concerned about the use of the computer for educational purposes; however, only when parents' computer literacy is sufficient, they tend to monitor children's computer use and to provide assistance while learning. Besides, studies show that those parents whose relationships with children are closer better control children's time at the computer and children spend more time at the computer learning than in those families where the relationships are not that close. The fact that closeness of family relationships has implications for safe behaviour on the Internet is also confirmed in studies conducted by Przybyła-Basista \& Kołodziej (2014). Parents whose computer literacy is higher better perceive dangers of the Internet and herewith spend more time with their children surfing the Internet, discuss various aspects of safe browsing, which makes them feel more capable to protect children from Internet hazards (Vitalaki et al., 2012).

Li et all. (2013) identified that strict parental control over adolescents can lead to a wish to protest; therefore, parents should draw adequate and understandable limitations, monitor and control, considering emotional 
background. The study conducted by Przybyła-Basista \& Kołodziej (2014), analysing how parents monitor and control behaviour of their children and adolescents (9-10 years old and 11-13 years old), revealed that parents controlling younger children expressed more emotional support and understanding.

The above-mentioned problems have prompted to conduct a study, the aim of which is to disclose peculiarities of children's, adolescents' and young people's use of virtual space and their attitude to parental control.

The research aim is concretised by the following problem questions:

What is typical children's, adolescents' and young people's behaviour on the Internet and what are the peculiarities of such behaviour with regard to gender?

How do children assess parents' monitoring and control?

What is educators' attitude to parental monitoring and control, to what extent does it coincide with students' standpoint?

Quantitative method- questionnaire survey - was applied in order to disclose peculiarities of children's, adolescents' and young people's use of virtual space and their attitude to parental control.

The questionnaire both for pupils and teachers consisted only of closedended questions. Each question consisted of the list of statements which respondents could rate using the 5-point rating scale: 5 points - definitely yes, 4 points - yes, 3 points - perhaps, 2 points - no, 1 point - definitely no. The questionnaires both for teachers and pupils consisted of 4 parts: one part was intended for statements defining various online actions. Another part was intended for identification of actions performed on the Internet and goals. The third part was devoted to statements defining parental control. In the fourth part respondents were asked to provide some information about themselves: age, gender, possession of the personal computer, to identify places in which they typically used the computer and the Internet connection.

Statistical data analysis of the quantitative research was carried out via computerized statistical data processing program (SPPS 19.0); descriptive statistics was applied, as well as, multidimensional statistical methods: factor analysis (method of analysis of principal components, Cronbach $\alpha$ coefficient was computed, VARIMAX rotation with Kaiser normalization, when applying factor weight $\mathrm{L}$; calculation of empirical indicators' frequencies (averages, percentage, standard deflections), and Pearson correlation analysis. Also was used student's t-test for testing tendency about the mean of parent's control from teachers' and pupils' point of view. To implement this aim the questionnaire survey method was chosen (respondents were offered to fill in the electronic or printed version of the questionnaire).

The questionnaire survey was attended by 189 children, adolescents and young people (69 boys and 114 girls), who were 10-20 years of age from different places of Lithuania and who studied in comprehensive schools, were 
educated at socialization centres or lived in children's care homes. 123 teachers and other participants of the educational process were also interviewed. During the survey teachers worked in different types of institutions: special schools (35\%), gymnasiums (21.1\%), basic schools (19.5\%), secondary schools $(8.9 \%)^{12}$, and other institutions. The vast majority of educators were women ( $88.6 \%$ of the respondents to this question), the average age was 42 years. In many cases respondents were both educators and parents $(74.8 \%$ indicated that they had one or more children), and therefore, it is likely that they answered the given questions about children's hobbies and habits related to the use of information computer technologies not only as educators but also as parents who had their experience and attitudes.

\section{Pupils' survey results}

Respondents were asked whether they had their own computer. Out of 184 children, adolescents and young people who answered this question 55 boys and 74 girls have their own computer. This makes up $70.11 \%$ of respondents who answered this question. 15 boys and 40 girls do not have their own computer. This represents $29.89 \%$ of respondents who answered this question. The vast majority of educators have the computer at home: one (48\%) or two and more (44.7\%). 4.9\% did not respond to this question; it is likely that they do not have the computer at home. Despite the fact that the majority of teachers have the computer at home, even 35\% reported that most often they used it at work.

Survey participants were asked whether and where they most commonly used the Internet. It was found that almost all respondents used the Internet (even 96.8\%) but in different places. The vast majority of pupils surveyed (95.2\% of pupils) have the Internet at home. One fourth $(25.9 \%)$ of them use the Internet at school, a small share, at the day centre $(2.1 \%)$, others, in another public space $(5.8 \%)$.

It was aimed to identify what boys and girls were usually doing on the Internet and whether there was a statistically significant difference between boys' and girls' typically performed actions on the Internet. The factor analysis $\operatorname{method}(\mathrm{KMO}=0.762)$ enabled the extraction of 7 groups of typical actions online: attract peers' attention by humour (0,863 $\geq L \geq 0,773)$; take interest in science news $(0,853 \geq L \geq 0,677)$; cherish/meet the sexual need $(0,799 \geq L \geq 0,682)$; develop acquaintances $(0,780 \geq L \geq 0,734)$; capture and distribute visual images $(0,731 \geq L \geq 0,716)$; express their view $(0,677 \geq L \geq 0,676)$; bully others / are bullied $(0,644 \geq L \geq 0,615)$. All of these groups representing typical actions online explain $62.5 \%$ of the total dispersion of typical actions that children, adolescents and young people perform online. The most important groups of inherent actions, explaining $22.5 \%$ of the total number of actions online are: cherish $/$ meet the

\footnotetext{
${ }^{12}$ Note: the sum of percentages exceeds 100 because educators work in more than one institution; therefore, they could choose several types of institutions.
} 
sexual need and capture and distribute visual images. Distinguished groups of typical actions online were analyzed applying the Student's criterion by gender for independent samples.

The analysis of typical actions performed online by gender is presented in Figure 1:

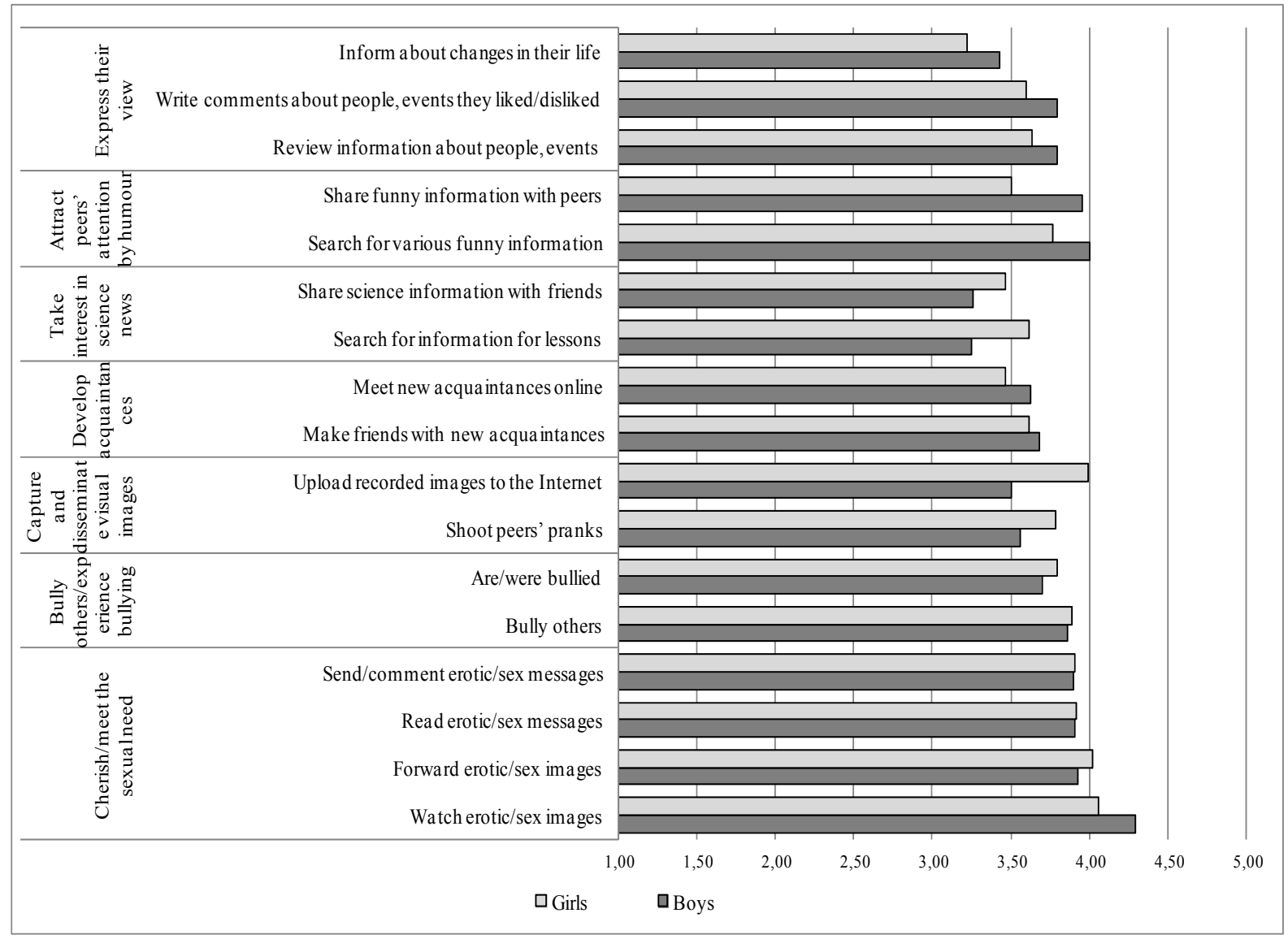

Figure. 1. Typical actions performed online by gender and action groups, $M$

The graph in Fig. 1 demonstrates only slight differences between typical actions performed by boys and girls on the Internet. The T-test for independent samples disclosed that the most significant differences between the means of boys' and girls' estimates were observed only with regard to attributes upload recorded images to the Internet and review their friends' messages, information. Girls $(\mathrm{M}=3.99, \mathrm{SD}=1.013)$ significantly more often than boys $(\mathrm{M}=3.50$, $\mathrm{SD}=1.530)$ uploadrecorded images to the Internet and review their friends' messages, information $(\mathrm{M}=4.14, \mathrm{SD}=1.690)$. The Student's criterion disclosed that there was a statistically significant difference between boys and girls only with regard to one action - uploadrecorded images to the Internet $(\mathrm{p}=0.019)$. The factor analysis did not disclose any other statistically significant differences between boys and girls with regard to typical actions on the Internet.

It was sought to identify how boys and girls understood goals for which they used virtual space. The factor analysis $(\mathrm{KMO}=0.657)$ enabled the 
extraction of the three types of such goals: virtual space is used for video and audio material $(0,842 \geq \mathrm{L} \geq 0,617)$, search for the news about events and people $(\mathrm{L}=0.796)$ and computer games for money $(\mathrm{L}=0.925)$. These factors reveal the exact size of $57.16 \%$ of the total use of web space.

Graphic comparison of the means of virtual space usage between boys and girls is presented in Figure 2.

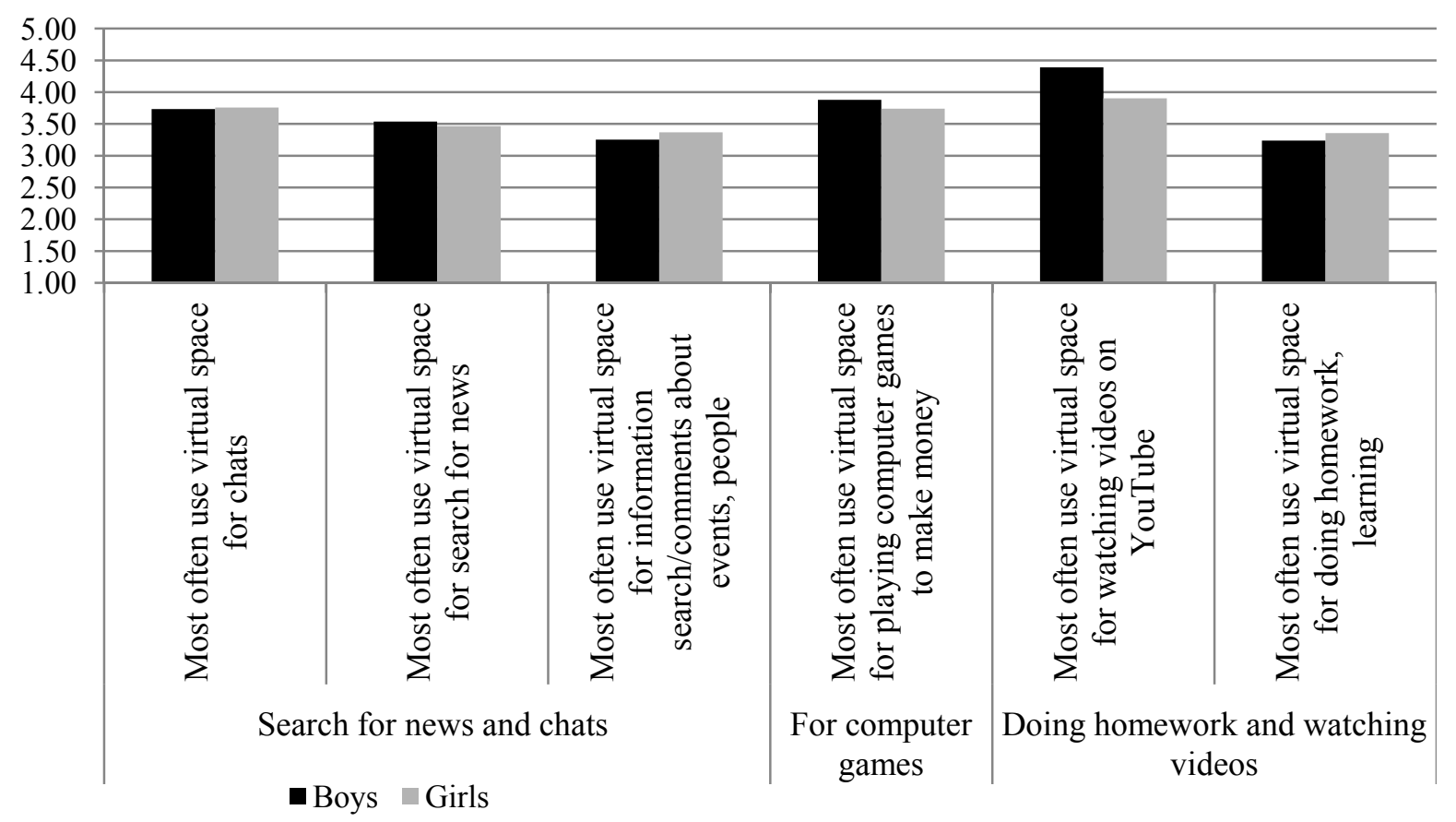

Figure. 2. The use of virtual space by gender, $M$

The graph in Figure 2 discloses that boys $(\mathrm{M}=3.88$; $\mathrm{SD}=1,605)$ more often use virtual space than girls $(\mathrm{M}=3.74 ; \mathrm{SD}=1.126)$ to view videos on YouTube. The Student's criterion was used to check whether this difference was statistically significant. The comparison of the means of boys' and girls' responses disclosed that there was no statistically significant difference rating the statement virtual space is mainly used for watching videos on You Tube ( $\mathrm{p}=$ 0.075 , when the level of significance $\mathrm{p}<0.05$ ), although graph columns show that boys $(\mathrm{M}=439, \mathrm{SD}=1.817)$ admit that they are doing this much more often than girls $(\mathrm{M}=3.90, \mathrm{SD}=1.770)$.

The questionnaire survey was used to assess whether respondents felt parental control with regard to their online activities and if they felt, what peculiarities were inherent to this control. The factor analysis $(\mathrm{KMO}=0.871)$ enabled to distinguish two types of pupils' opinions with regard to parental control. Pupils tend to assess parental control with regard to their online activities neutrally, as parental monitoring $(0,682 \geq \mathrm{L} \geq 0,613)$. Such type of students' approach encompasses $26.58 \%$ of the surveyed population. Much less often pupils perceive parental control with regard to their online activities as 
strict and assertive $(0,830 \geq \mathrm{L} \geq 0,672)$. This type of pupils' approach is limited to only $19.82 \%$ of the respondents' population.

Two groups of factors, obtained during the factor analysis, were tested by the Student's criterion for independent (boys' and girls') samples. Results of this analysis enabled to compare how boys and girls perceived parental control with regard to their online activities. Comparison data are presented in Figure 3:

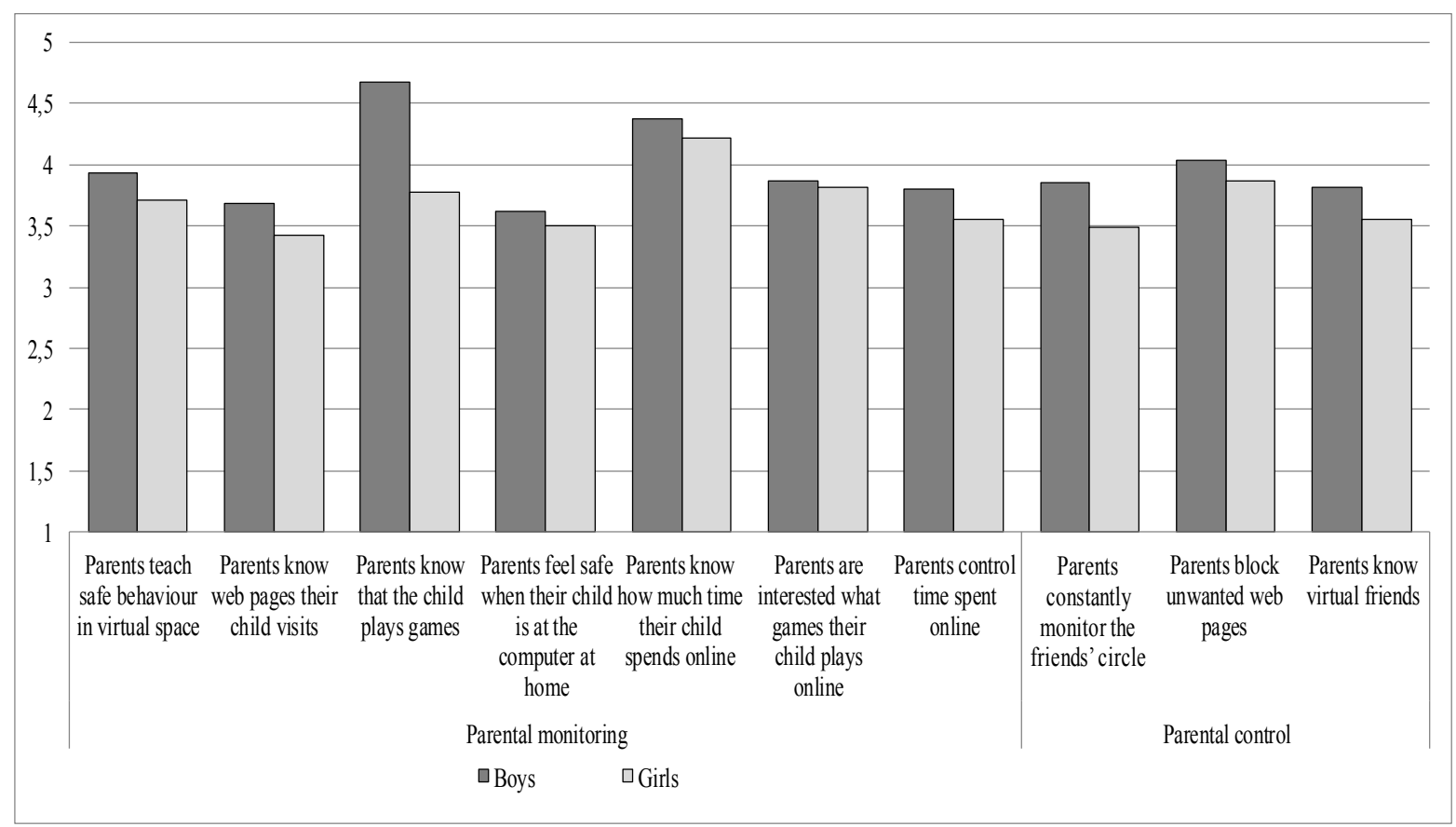

Figure. 3. Pupils' attitude to parental control with regard to the use of the computer and virtual space, $M$

Answering questionnaire questions, boys were more inclined than girls to rate each statement about parental control giving higher estimate (see Fig. 3): it is likely that girls are just more obedient and take monitoring and control for granted.

The analysis of statements about parental monitoring and parental control factors by gender, applying the T-test for independent samples, dislosed statistically significant difference between boys' and girls' samples only with regard to one statement parents know that the child plays computer games $(p=0,001$, when the significance level $p<0,05)$.

\section{Educators' and pupils' survey results}

Educators'and pupils' attitudes towards parental control with regard to the use of the computer and virtual space were compared. The comparative analysis revealed that both pupils and teachers felt and knew that parents controlled pupils' activities on the Internet to a greater or lesser extent. Detailed data of the comparative analysis are presented in Figure 4. 
Both teachers and pupils claim that parents know that their children play computer games. The number of teachers sharing this view $(\mathrm{M}=4.04 ; \mathrm{SD}=$ $1.33)$ is less than the number of pupils $(\mathrm{M}=4.48, \mathrm{~S}=1.69)$. $\mathrm{SD}$ witnesses that a share of children conceal that they play games from their parents and think that their parents do not know about that. Pupils are confident $(\mathrm{M}=4.97$; $\mathrm{SD}=1.27)$ that parents know how much time they spend online, while educators believe that parents are poorly informed about that $(\mathrm{M}=3.57$; $\mathrm{SD}=1.18)$. Both pupils and teachers know that children spend part of the time online. However, both the former and the latter believe that parents are little aware of what web pages children visit $\left(\mathrm{M}_{\text {(teacher) }}=3,23 ; \mathrm{SD}_{\text {(teacher) }}=1,12 ; \mathrm{M}_{\text {(pupil) }}=3,62 ; \mathrm{SD}_{\text {(pupil) }}=1,72\right)$. High SD shows that some children are very strictly controlled in this aspect, while others are not controlled at all. The fact that parents do not quite know what sites their children visit leads to the fact that undesirable web pages are rarely blocked $\left(\mathrm{M}_{\text {(teacher) }}=2.85 ; \mathrm{SD}_{\text {(teacher) }}=1.26 ; \mathrm{M}_{\text {(pupil) }}=2.12 ; \mathrm{SD}_{\text {(pupil) }}=1.53\right)$. Both children $(\mathrm{M}=4.19 ; \mathrm{SD}=1.57)$ and educators $(\mathrm{M}=4.67 ; \mathrm{SD}=1.05)$ believe that parents feel quite safe when the child is sitting at the computer at home. In the opinion of both groups of respondents parents are least inclined to follow and monitor the circle of the child's friends $\left(\mathrm{M}_{\text {(teacher) }}=3.14 ; \mathrm{SD}_{\text {(teacher) }}=1.16\right.$; $\mathrm{M}_{(\text {pupil) }}=2.77 ; \mathrm{SD}_{\text {(pupil) }}=1.63$ )

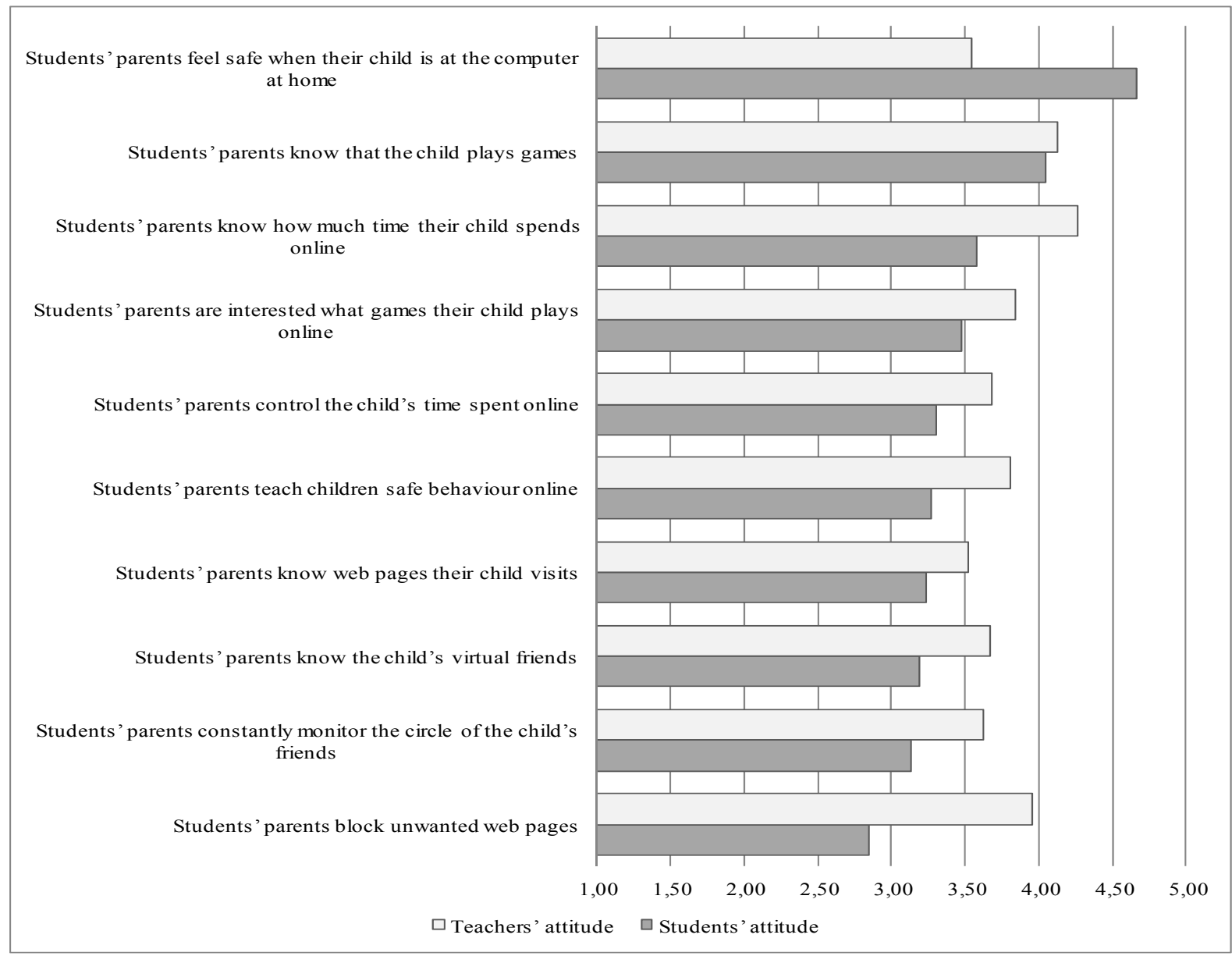

Fig. 4. Teachers' and pupils' approach to parental control, $M$ 
The comparison of teachers' and pupils' survey results (see Fig. 4) using the T-test for independent samples resulted in statistically significant difference between teachers' and pupils' attitude with regard to statements defining control of the majority of parents (see Table 1).

Table 1. Differences of teachers' and pupils' approach to parental control

\begin{tabular}{|c|c|c|c|c|c|c|c|}
\hline \multirow{2}{*}{$\begin{array}{l}\text { Statements defining } \\
\text { parental control }\end{array}$} & \multicolumn{2}{|l|}{$\mathbf{M}$} & \multicolumn{2}{|l|}{ SD } & \multirow{2}{*}{$\mathbf{t}$} & \multirow{2}{*}{ df } & \multirow{2}{*}{$p<0,05$} \\
\hline & Teachers & Pupils & Teachers & Pupils & & & \\
\hline $\begin{array}{l}\text { Students' parents know how } \\
\text { much time the child spends } \\
\text { on the Internet }\end{array}$ & 3,5726 & 4,9719 & 1,18406 & 1,27306 & $-9,492$ & 293 &, 000 \\
\hline $\begin{array}{l}\text { Pupils' parents block } \\
\text { unwanted web pages }\end{array}$ & 2,8522 & 2,1243 & 1,25826 & 1,52864 & 4,254 & 290 &, 000 \\
\hline $\begin{array}{l}\text { Pupils' parents feel safe } \\
\text { when the child is at the } \\
\text { computer at home }\end{array}$ & 4,6667 & 4,1932 & 1,05045 & 1,57377 & 3,088 & 290,992 &, 002 \\
\hline $\begin{array}{l}\text { Pupils' parents know that } \\
\text { the child plays games }\end{array}$ & 4,0431 & 4,4830 & 1,32791 & 1,69360 & $-2,478$ & 281,295 &, 014 \\
\hline $\begin{array}{l}\text { Pupils' parents know web } \\
\text { pages visited by the child }\end{array}$ & 3,2308 & 3,6158 & 1,12483 & 1,71536 & $-2,325$ & 291,988, &, 021 \\
\hline $\begin{array}{l}\text { Pupils' parents constantly } \\
\text { monitor the circle of the } \\
\text { child's friends }\end{array}$ & 3,1379 & 2,7740 & 1,15643 & 1,63234 & 2,232 & $|289,206|$, &, 026 \\
\hline
\end{tabular}

Although the means of teachers' and pupils' estimates reveal the same tendency of approval or disapproval of statements defining parental control, there are statistically significant differences between teachers' and pupils' attitudes with regard to the majority of statements. The majority of pupils ( $\mathrm{M}=$ 4.97; $\mathrm{SD}=1.27$ ) tend to strongly acknowledge that parents know how much time their child spends online, but teachers tend to strongly doubt it $(\mathrm{p}=0.000)$. Pupils also admit that parents know that the child plays games $(\mathrm{M}=4.48 ; \mathrm{SD}=$ 1.69) or know what websites the child visits $(\mathrm{M}=3.62 ; \mathrm{SD}=1.72)$, but teachers are significantly less confident of such parents' awareness $(\mathrm{M}=4.04 ; \mathrm{SD}=1.33$ and $\mathrm{M}=3.23 ; \mathrm{SD}=1.12 ; \mathrm{p}=0.014$ and $\mathrm{p}=0.021$ ).

Teachers tend to approve of statements defining stricter parental control; for example, parents block unwanted websites $(\mathrm{M}=2.8522$; $\mathrm{SD}=1.26)$ or parents constantly monitor the circle of the child's friends $(\mathrm{M}=3.14 ; \mathrm{SD}=$ 1.16), but pupils assess that parental control much more sceptically $(\mathrm{M}=2.12$; $\mathrm{SD}=1.53 ; \mathrm{p}=0.000$ and $\mathrm{M}=2.77 ; \mathrm{SD}=1.63 ; \mathrm{p}=0.026)$.

\section{Generalisations and Conclusions}

The vast majority of respondents - more than two thirds of pupils and almost all educators - have the personal computer. Less than one tenth of respondents did not answer this question. However, the computer plays a 
completely different role in pupils' and educators' life. While students try to use it as often as possible both at home and at school, for entertainment and learning, a considerable share of teachers use the computer only for work purposes because although they have it at home, they still use only at work.

Groups of pupils' typical online actions are: attract peers' attention by humour; take interest in science news; cherish/meet the sexual need; develop acquaintances; capture and distribute visual images; express their views; bully others/are bullied. The key groups of typical actions are: cherish/meet the sexual need and capture and distribute images. Statistically significant difference between boys and girls with regard to typical actions performed on the Internet was found only with regard to the action upload shot images on the Internet: girls perform this action considerably more often than boys. The study supports the opinion that the Internet is a dangerous place for pupils: entertaining themselves, they often encounter information containing dangerous content, make new contacts there.

Boys and girls perceive why they surf the Net. The factor analysis enabled to distinguish three reasons for surfing the Internet: for video and audio material, search for the news about events and people and computer games for money. Statistically significant differences between boys and girls with regard to goals of using virtual space have not been identified.

The factor analysis enabled to identify two types of parental control with regard to the use of the computer and virtual space: parental monitoring and parental control. Statistically significant difference between boys' and girls' samples was identified only with regard to one statement parents know that the child plays computer games. The tendency can be envisaged that girls subjectively feel parental control more than boys. Among other things, survey results suggest that in families virtual space hazards are perceived differently and parents' activeness monitoring and controlling children differs considerably: some pupils are quite heavily controlled, others, not.

Statistically significant differences between pupils' and teachers' attitudes towards parental control with regard to the use of the computer and virtual space came to prominence: children maintain that parents control and monitor them. Such approach is more inherent to boys than to girls, while educators believe that parents are quite careless with regard to children's use of the computer and virtual space. Both teachers and pupils maintain that parents feel quite safe when their children spend their time at the computer but teachers are more confident about that than pupils. Although pupils' opinions about parents' awareness of their surfed web pages differ, in both pupils' and educators' opinions, parents little know what web pages their children visit, they insufficiently monitor their friends' circle. 


\section{SOCIETY. INTEGRATION. EDUCATION. Volume IV}

\section{References}

Brazdeikis, V. (2003). Pedagogo kompetencija, informacinių ir komunikacinių technologijų diegimas švietime. Informacijos mokslai, 26, 29-34.

Dagienè, V. (2003). Informacinių technologijų taikymo švietime, konceptualusis pagrindimas. Informacijos mokslai, 25 (pp.127-133).

Giles, G., Price, I. A. (2008). Adolescent computer use: Approach, avoidance, and parental control. Australian Journal of Psychology, Vol. 60, No. 2, 63-71.

Yu, M., Yuen, A. H. K, Park, J. (2012). Students' computer use at home: a study on family environment and parental influence. Research and Practice in Technology Enhanced Learning, Vol. 7, No. 1, 3- 23.

Laurutis, V., Gumuliaus, A., Šaparnyte, E. (2003). Informacinių ir komunikacinių technologiju integravimo švietimo sistemoje tendencijos nuolatinio mokymosi kontekste. Pedagogika, 69, 112-121.

Li, X., Li, D., Newman, J. (2013). Parental Behavioral and Psychological Control and Problematic Internet Use Among Chinese Adolescents: The Mediating Role of SelfControl. Cyberpsychology, Behavior, and Social Networking. Volume 16, No 6, 44247.

Markauskaitè, L., Dagienė, V. (2001). Informacinių ir komunikacinių technologijų diegimo Lietuvos švietime strategijos teorinis pagrindimas. Socialiniai mokslai 1 (27), 29-39.

Masiliauskienè, E. (2009). Vaikų kompiuterinès kultūros sklaidos sąlygos namų aplinkoje: kompiuterio svarba vaikui ir jo dalyvavimas kompiuterinèje veikloje. Jaunuju mokslininku darbai. No 2, 167-173)

Przybyła-Basista, H., Kołodziej, A. (2014). Parental Monitoring of the Internet Activity of Young Children and Preadolescents. TheNewEducationalReview. Vol. 35, No. 2, 315325. 